\title{
Mitochondrial DNA depletion syndrome, hepatocerebral form due to DGUOK deficiency
}

INSERM

\section{Source}

INSERM. (1999). Orphanet: an online rare disease and orphan drug data base. Mitochondrial DNA depletion syndrome, hepatocerebral form due to DGUOK deficiency. ORPHA:279934

A rare, genetic, mitochondrial DNA depletion syndrome characterized by severely reduced mitochondrial DNA content due to DGUOK deficiency typically manifesting with early-onset liver dysfunction, psychomotor delay, hypotonia, rotary nystagmus that develops into opsoclonus, lactic acidosis and hypoglycemia. 